\title{
The Application of an Adaptive Controller Combined with the LQR Controller for the Inverted Pendulum
}

\author{
Jakub Żegleń \\ AGH Akademia Górniczo-Hutnicza, Wydział Elektrotechniki, Automatyki, Informatyki i Inżynierii Biomedycznej, al. Adama Mickiewicza 30 \\ 30-059 Kraków
}

\begin{abstract}
The inverted pendulum is an unstable system with nonlinear dynamics. The task of controlling the inverted pendulum is complex. Therefore, the inverted pendulum over the years has become one of the most important systems on which every controller is tested. Here the objective is to control the system in such a way that the inverted pendulum stabilizes in the upright position. This analysis proposes a non-linear Lyapunov-based controller. The controller at hand, only provides the pendulum's stabilization, therefore an additional module is needed - in this case the LQR controller. Both modules are combined with each other by using a two-loop parallel design. The newly designed controller has been experimentally tested and compared to the single LQR controller.
\end{abstract}

Keywords: inverted pendulum, adaptive controller, LQR

\section{Introduction}

In control systems many controllers are implemented for managing various types of processes. The most popular are: the PID (proportional-integral-derivative) and the LQR (linear-quadratic regulator). Over many years computers gained much more computing power which allowed for more calculations to be done in a shorter period of time. As a result, scientists and engineers began to introduce more advanced variants of controllers. Examples include control algorithms based on the mathematical model of the Model-Based-Design [19], adaptive controllers using the Lyapunov theorem $[8,20]$ or neural networks $[4,5]$.

The inverted pendulum is an unstable system with nonlinear dynamics. It is an example of the under actuated system - there are less inputs than numbers of degrees of freedom [17]. This is the reason why the task of controlling the inverted pendulum is difficult. Therefore, the inverted pendulum over the years has become one of the most important systems on which every controller is tested. The extension of the inverted pendulum system is a double inverted pendulum system [16]. That system is even more unstable and more difficult to control.

There are many articles presenting various implementations of controllers for the inverted pendulum. The most popular are the PID [11-13] and the LQR [13, 14, 23] controllers. There are also more articles with advanced functions like the Lyapunov the-

\section{Autor korespondujący:}

lakub Żegleń, zeglenjakub@gmail.com

\section{Artykuł recenzowany}

nadesłany 03.07.2019 r., przyjęty do druku 22.11.2019 r.

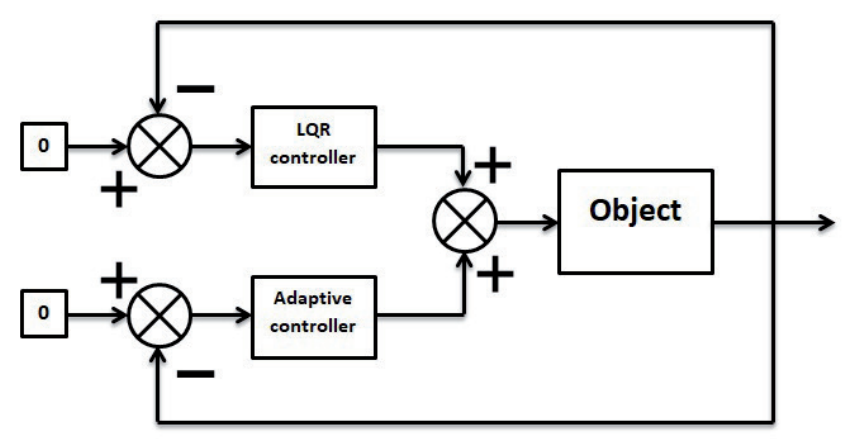

Fig. 1. Block diagram of the system with two parallel controllers Rys. 1. Schemat blokowy systemu z dwoma równoległymi regulatorami

orem based controller $[1,2,15,26]$ and the fuzzy neural network controller $[6,14,24,25]$.

This paper proposes to combine the LQR controller with the more advanced adaptive controller based on Lyapunov theorem. This effect can be achieved by using a two-loop parallel design (fig. 1). One loop uses the standard LQR controller and the second one uses the adaptive controller. There is a need to construct a control function of Lyapunov to guarantee stability [3].

This article is organized in five chapters. Chapter 2 shows the equations used to describe the inverted pendulum system. Chapter 3 describes designing specific controller - combination of LQR and the adaptive controller. Chapter 4 presents experimental results of the proposed controller with quality indicators. Chapter 5 is a summary with conclusions.

\section{The mathematical model of the inverted pendulum}

Consider an inverted pendulum on a cart that can move only in one direction on rails with two rods attached to it. A typical inverted pendulum system is shown in figure 2 together with 
the forces and system variables (described at the end of the chapter). This system has infinite equilibrium points, but the two most important ones are:

- the stable one - the pendulum is directed vertically downwards,

- the unstable one - the pendulum is directed vertically upwards.

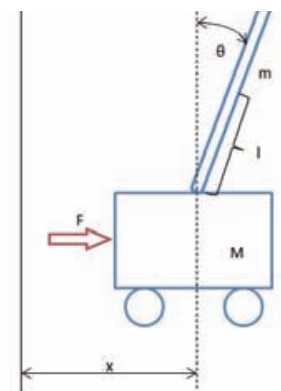

Fig. 2. Diagram of the inverted pendulum [17]

Rys. 2. Schemat układu wahadła odwróconego [17]

The goal is to stabilize the system in its unstable position, where pendulum is directed vertically upwards. The equations of motion can be derived using Lagrangian equation as follows [22]:

$$
L=K-U
$$

where: $K$ - kinetic energy, $U$ - potential energy.

The $x$ position of the pendulum is $x+\operatorname{lin} \theta$ and the $y$ position is $l \cos \theta$, so the kinetic energy is:

$$
K=\frac{1}{2} M \dot{x}^{2}+\frac{1}{2} m\left[\frac{d}{d t}(x+l \sin \theta)\right]^{2}+\frac{1}{2} m\left[\frac{d}{d t}(l \cos \theta)\right]^{2}
$$

By simplifying the above equation, the following formula for kinetic energy can be obtained:

$$
K=\frac{1}{2}(M+m) \dot{x}^{2}+m l \dot{x} \dot{\theta} \cos \theta+\frac{1}{2} m l^{2} \dot{\theta}^{2}
$$

The potential energy is as follows:

$$
U=m g l(1-\cos \theta)
$$

Combining both equations, the Lagrangian equation of the system is:

$$
L=\frac{1}{2}(M+m) \dot{x}^{2}+m l \dot{x} \dot{\theta} \cos \theta+\frac{1}{2} m l^{2} \dot{\theta}^{2}-m g l(1-\cos \theta)
$$

$$
\text { Clearly } \frac{\partial L}{\partial x}=0 \text { and }
$$

$$
\frac{\partial L}{\partial \dot{x}}=(M+m) \dot{x}+m l \dot{\theta} \cos \theta
$$

SO

$$
\frac{d}{d t}\left(\frac{\partial L}{\partial \dot{x}}\right)=(M+m) \ddot{x}+m l \ddot{\theta} \cos \theta-m l \dot{\theta}^{2} \sin \theta=F
$$

The next step is to consider the $\theta$ direction and velocity:

$$
\frac{\partial L}{\partial \theta}=-m l \dot{x} \dot{\theta} \sin \theta+m g l \dot{\theta} \sin \theta
$$

and

$$
\frac{\partial L}{\partial \dot{\theta}}=m l \dot{x} \cos \theta+m l^{2} \dot{\theta}
$$

By calculating the derivative of time, the following equation can be obtained:

$$
\frac{d}{d t}\left(\frac{\partial L}{\partial \dot{\theta}}\right)=(m l \ddot{x} \cos \theta-m l \dot{x} \dot{\theta} \sin \theta)+m l^{2} \ddot{\theta}
$$

Therefore the Lagrangian equation of motion is:

$$
m l(\ddot{x} \cos \theta+l \ddot{\theta}-g \sin \theta)=0
$$

Finally, the general equations of the inverted pendulum system are [3]:

$$
\begin{gathered}
(M+m) \ddot{x}+m l \ddot{\theta} \cos \theta-m l \dot{\theta}^{2} \sin \theta=F \\
\ddot{x} \cos \theta+l \ddot{\theta}-g \sin \theta=0
\end{gathered}
$$

The next step is to determine the $F$ force in the system

$$
F=m g \sin \theta \cos \theta+\frac{(g \cos \theta-u)+\left(M+m \sin ^{2} \theta\right)}{\cos \theta}
$$

Additionally, the state vector is described as below:

$$
\mathbf{x}=\left[\begin{array}{llll}
\theta & \dot{\theta} & x & \dot{x}
\end{array}\right]^{\mathrm{T}}
$$

This $\mathbf{x}$ can be extended to:

$$
\begin{gathered}
\dot{x}_{1}=x_{2} \\
\dot{x}_{2}=\varphi_{4}+\frac{u}{l} \\
\dot{x}_{3}=x_{4} \\
\dot{x}_{4}=\varphi_{2}-\frac{u}{\cos x_{1}}
\end{gathered}
$$

where:

$$
\begin{gathered}
\varphi_{2}=g \tan \left(x_{1}\right)+\frac{m l \sin \left(x_{1}\right) x_{2}^{2}}{M+m \sin ^{2}\left(x_{1}\right)} \\
\varphi_{4}=-\frac{m \sin \left(x_{1}\right) \cos \left(x_{1}\right) x_{2}^{2}}{M+m \sin ^{2}\left(x_{1}\right)}
\end{gathered}
$$

$F$ - force applied to the cart,

$x$ - cart position,

$m$ - mass of the pendulum,

$M$ - mass of the cart,

$\theta$ - pendulum angle,

$g$ - standard gravity,

$l$ - half the length of the pendulum,

$u$ - control signal.

\section{Controller design}

The goal of the controller is to stabilize the rod of an inverted pendulum in vertically upwards position with the cart in the starting position. One of the easiest ways to accomplish that is to use the LQR algorithm. Since this controller is very basic, it can be enhanced - combined with another controller. In this paper the LQR is combined with an adaptive controller based 
on Lyapunov theorem. This effect can be achieved by using a two-loop parallel design.

Figure 3 shows the block diagram of the inverted pendulum control system. It can be seen that the PLC is connected to a power interface and a PC. The power interface provides the required power to a DC motor and adjusts the measuring signals from incremental encoders. The computer was used to monitor and acquire process variables and also to implement applications for the PLC.

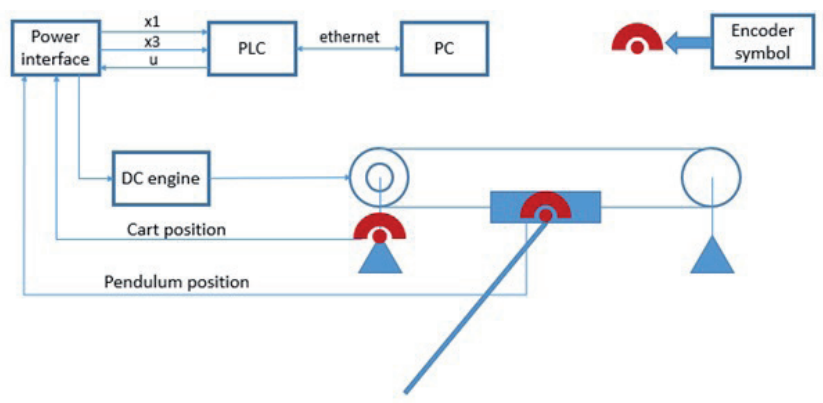

Fig. 3. Block diagram of the inverted pendulum system

Rys. 3. Schemat blokowy układu regulacji wahadłem odwróconym

In order to prepare an adaptive controller, there is a need to develop a control law without taking into consideration the position or velocity [3]. This system assumes that the rod's length is unknown. Lyapunov law will guarantee the stability of the inverted pendulum. The first step to implement the controller is to define the position error of the pendulum:

$$
\xi_{3}=x_{3}-\theta_{s p}
$$

Then using Lyapunov function:

$$
V\left(\xi_{3}\right)=\frac{1}{2} \xi_{3}^{2}
$$

The first virtual control can be received:

$$
x_{4 d}=-k_{3} \xi_{3}+\dot{\theta}_{s p}
$$

where: $k_{3}>0, \theta_{s p}-$ pendulum set angle.

The next step is to define the second error variable:

$$
\xi_{4}=x_{4}-x_{4 d}=x_{4}+k_{3} \xi_{3}+\dot{\theta}_{s p}
$$

State variables (26) and (27) can be written in space $\left(\xi_{3}, \xi_{4}\right)$ as:

$$
\begin{gathered}
\dot{\xi}_{3}=-k_{3} \xi_{3}+\xi_{4} \\
\dot{\xi}_{4}=-k_{3}^{2} \xi_{3}+k_{3} \xi_{4}-\ddot{\theta}_{s p}+\varphi_{4}+\frac{u}{l}
\end{gathered}
$$

In that case Lyapunov function is expressed as follows:

$$
V\left(\xi_{3}, \xi_{4}\right)=\frac{1}{2} \xi_{3}^{2}+\frac{1}{2} \xi_{4}^{2}
$$

But due to the fact that length $l$ is not known, an estimate $\hat{l}$ is needed. In that case, the control should be modified:

$$
u=-\hat{l}\left[\left(k_{3}+k_{4}\right) \xi_{4}+\left(1-k_{3}^{2}\right) \xi_{3}-\ddot{\theta}_{s p}+\varphi_{4}\right]
$$

The final form of Lyapunov function is shown below:

$$
V\left(\xi_{3}, \xi_{4}, \hat{l}\right)=\frac{1}{2} \xi_{3}^{2}+\frac{1}{2} \xi_{4}^{2}+\frac{1}{2 l y}(\hat{l}-l)^{2}
$$

Everything above allows to introduce an adaptation:

$$
\dot{\hat{l}}=\gamma \xi_{4}\left[\left(k_{3}+k_{4}\right) \xi_{4}+\left(1-k_{3}^{2}\right) \xi_{3}-\ddot{\theta}_{s p}+\varphi_{4}\right]
$$

where $\gamma$ is an adaptive gain. Lyapunov function described above is negative, which means, that the whole system with the closed loop is globally asymptotically stable.

The second part of this controller is LQR. Consider the state-space equation [7]:

$$
\dot{\mathbf{x}}=A \mathbf{x}+B u
$$

where:

$$
\mathbf{x}=\left[\begin{array}{llll}
\theta & \dot{\theta} & x & \dot{x}
\end{array}\right]^{\mathrm{T}}
$$

The state feedback control is $u=-K \mathbf{x}$. Additionally cost function is given:

$$
J=\int\left(\mathbf{x}^{\mathrm{T}} Q \mathbf{x}+u^{\mathrm{T}} R u\right) d t
$$

where: $Q \geq 0, R>0$ and $Q$ is semi-definite and $R$ is a definite symmetric constant matrices.

Vector $K$ is computed from:

$$
K=R^{-1} B^{\mathrm{T}} P
$$

where $P$ is a positive definite symmetric matrix that can be obtained from an algebraic Riccati equation:

$$
A^{\mathrm{T}} P+P A-P B R^{-1} B^{\mathrm{T}} P+Q=0
$$

Matrices $Q$ and $R$ were selected in an experimental way. The following values allowed for satisfying the inverted pendulum control:

$$
\begin{gathered}
Q=\left[\begin{array}{cccc}
50 & 0 & 0 & 0 \\
0 & 100 & 0 & 0 \\
0 & 0 & 15 & 0 \\
0 & 0 & 0 & 10
\end{array}\right] \\
R=56.25
\end{gathered}
$$

Using the MATLAB, vector $K$ was calculated as:

$$
K=\left[\begin{array}{llll}
0.9428 & 5.0890 & 1.5597 & 1.0264
\end{array}\right]
$$

With formulas (16), (17), (18), (19) it was possible to obtain a plot of the poles of the inverted pendulum system (fig. 4). It can be seen that some of the poles are outside of the circle with a radius of 1 and a center at $(0,0)$, which confirms that the inverted pendulum is an unstable system.

Continuing the calculations in the MATLAB, the system with the inverted pendulum can be closed together with the appropriate controller. The figure 5 shows a plot of the poles of a closed system. This time, all poles are inside a circle with a radius of 1 and a center at $(0,0)$. This means that the inverted pendulum system has become stable. 


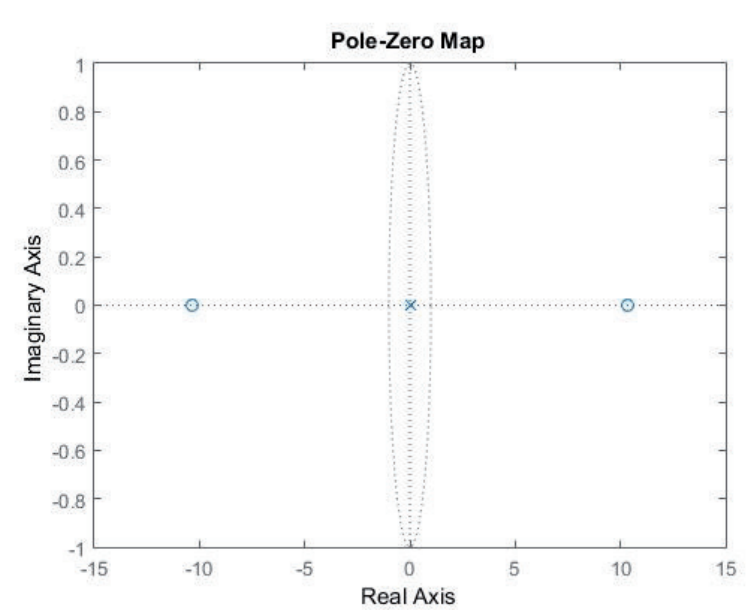

Fig. 4. The inverted pendulum open system poles

Rys. 4. Bieguny systemu otwartego wahadła odwróconego

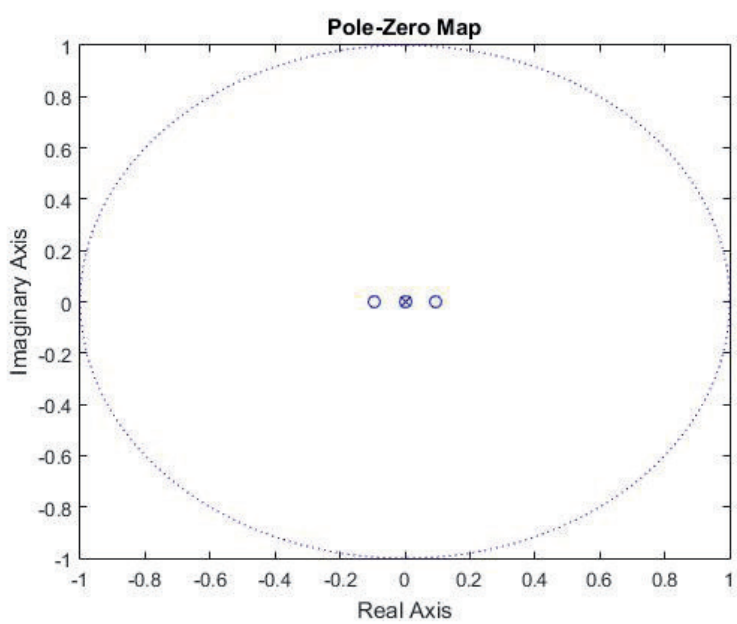

Fig. 5. The inverted pendulum closed system poles Rys. 5. Bieguny systemu zamkniętego wahadła odwróconego

\section{Simulation and experimental results}

The parameters of the inverted pendulum used in the simulation and experiment were as follows:

$M=0.548 \mathrm{~kg}$ - mass of the cart,

$m=0.11 \mathrm{~kg}-$ mass of the pendulum,

$g=9.80 \mathrm{~m} / \mathrm{s}^{2}-$ standard gravity,

$l=0.1436 \mathrm{~m}-$ half the length of the pendulum,

$b=1.5 \mathrm{~kg} / \mathrm{s}-$ coefficient of friction,

$I_{0}=0.0023 \mathrm{~kg} \cdot \mathrm{m}^{2}-$ moment of inertia of the pendulum.

Firstly, the simulation was performed in the MATLAB/ Simulink environment. The implementation of the simulation is shown in figure 6 . Both controllers are located in the middle of the figure. Using the switch block it was possible to control the choice of the regulator used in the simulation.

The results of the simulations are shown on figures 7 (the LQR version) and 8 (the adaptive version). It can be seen that the pendulum was held vertically upwards in both simulations.

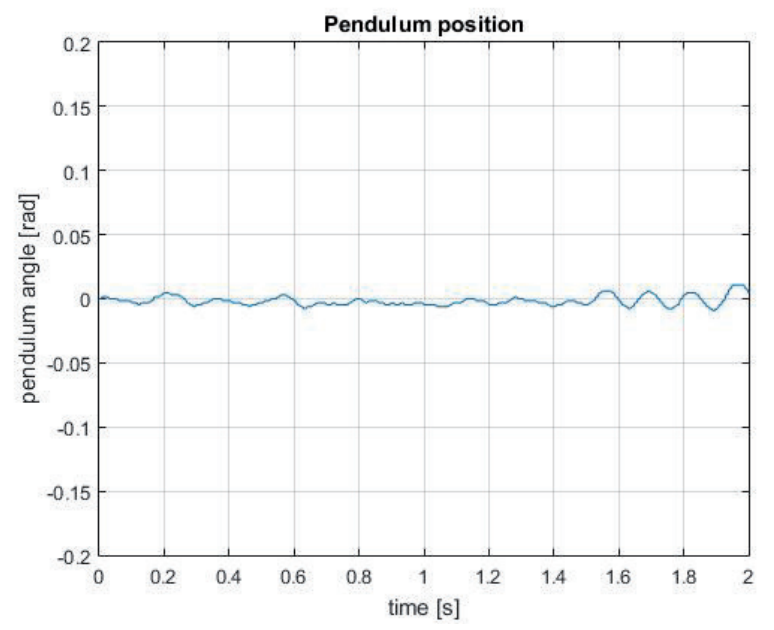

Fig. 7. Pendulum angle (LQR) during the simulation Rys. 7. Kąt wychylenia wahadła (LQR) - symulacja

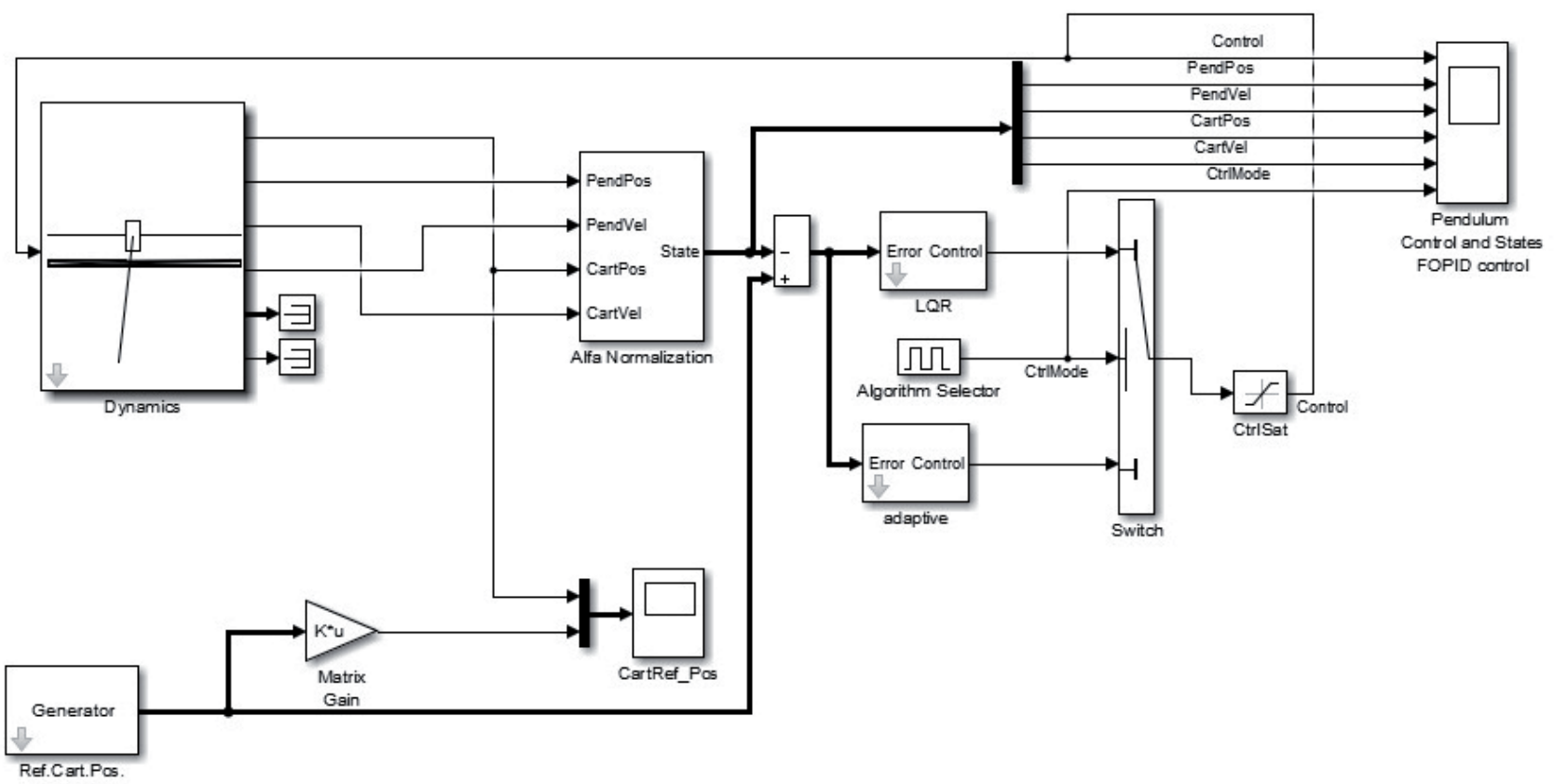

Fig. 6. Simulation of the inverted pendulum system

Rys. 6. Symulacja układu z wahadłem odwróconym 


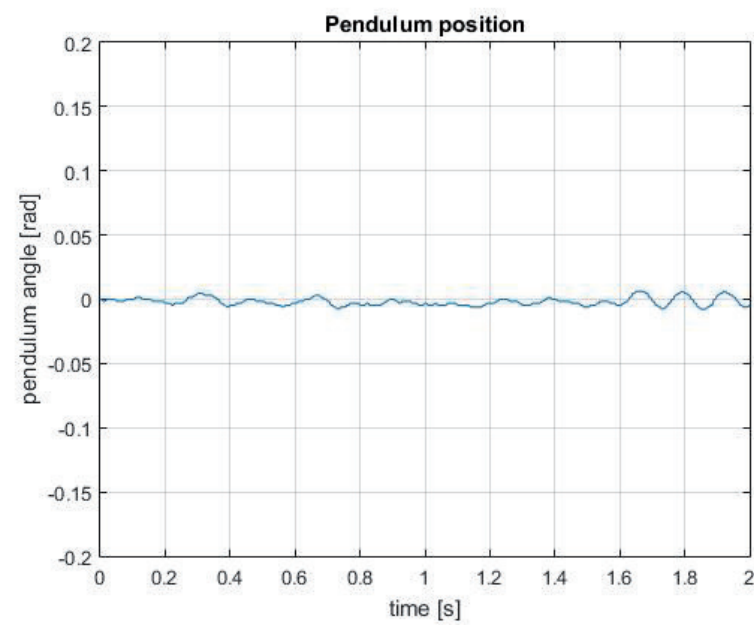

Fig. 8. Pendulum angle (adaptive) during the simulation Rys. 8. Kąt wychylenia wahadła (regulator adaptacyjny) - symulacja

The cost function was used to calculate the efficiency of both controllers. For this purpose, the most popular indicator was used - the Integral Square Error cost function:

$$
I=\int_{0}^{\infty}\left[E_{n}(t)\right]^{2} d t
$$

The results of the Integral Square Error cost function for both controllers are shown in table 1 .

Tab. 1. Integral indexes - steady states

Tab. 1. Wskaźniki całkowe - stany ustalone

\begin{tabular}{|c|c|}
\hline & Integral indexes \\
\hline LQR & 0.0527 \\
\hline Adaptive with LQR & 0.0507 \\
\hline
\end{tabular}

The first implementation of controllers was carried out in the MATLAB/Simulink, because this environment is more friendly when debugging. If everything works correctly then a second implementation can be carried out on the PLC. Due to the fact that the Simulink diagrams are more readable than the source code written for the PLC, in the further part of the article the implementation of individual controllers is illustrated using diagrams from Simulink.
The final experiments were performed using the PLC controller - ILC 350 PN made by Phoenix Contact company [18]. In order to prepare the system, the PLC controller was connected to the power interface through digital input/output modules, which were connected to the central unit. The following modules were used: IB IL INC-IN-PAC (incremental encoder support - two pieces - one for the cart and one for the pendulum) [9] and IB IL PWM/2-PAC (PWM signal generation) [10]. The most important specifications about the PLC have been collected in the table 2 .

In the first case the LQR controller was used on the inverted pendulum system. The implementation of this controller is shown in figure 9. The LQR controller is located on the left side of the diagram. This is a block called Gain that multiplies the input by a matrix $K$. All four states of the system are brought to it: the position of the pendulum, the speed of the pendulum, the position of the cart and the speed of the cart. The calculated control is fed to the block with saturation - it is designed to prevent engine damage. In addition, virtual limit sensors have been introduced to prevent the cart from colliding with the rail edges. The experiment was performed on the PLC controller. The algorithm operated in the $10 \mathrm{~ms}$ interval with the priority set to 0 .

The results of the first experiment are shown in figure 10. The pendulum was initially at the upper balance point. It does not fall down and maintains its vertical upright position.

In the second experiment, external disturbances were introduced - gentle prodding of the pendulum with a hand. Results are shown in figure 11. It can be seen on the chart that the pendulum is initially in the set position. However, a disturbance has been introduced. The system returns to the set state very quickly.

Tab. 2. ILC $350 \mathrm{PN}$ - specifications [21]

Tab. 2. ILC $350 \mathrm{PN}$ - specyfikacja [21]

\begin{tabular}{|c|c|}
\hline Processor & $400 \mathrm{MHz}$ \\
\hline Speed & $\begin{array}{c}0.5 \mathrm{~ms} \\
\text { for } 1 \mathrm{~K} \text { instructions }\end{array}$ \\
\hline Shortest cycle time & $1 \mathrm{~ms}$ \\
\hline Program memory & $\begin{array}{c}1 \mathrm{MB}, \\
\text { Data memory }\end{array}$ \\
\hline Memory for retentive data & $2 \mathrm{MB}$ \\
\hline Number of control tasks & $64 \mathrm{~KB}$ NVRAM \\
\hline
\end{tabular}

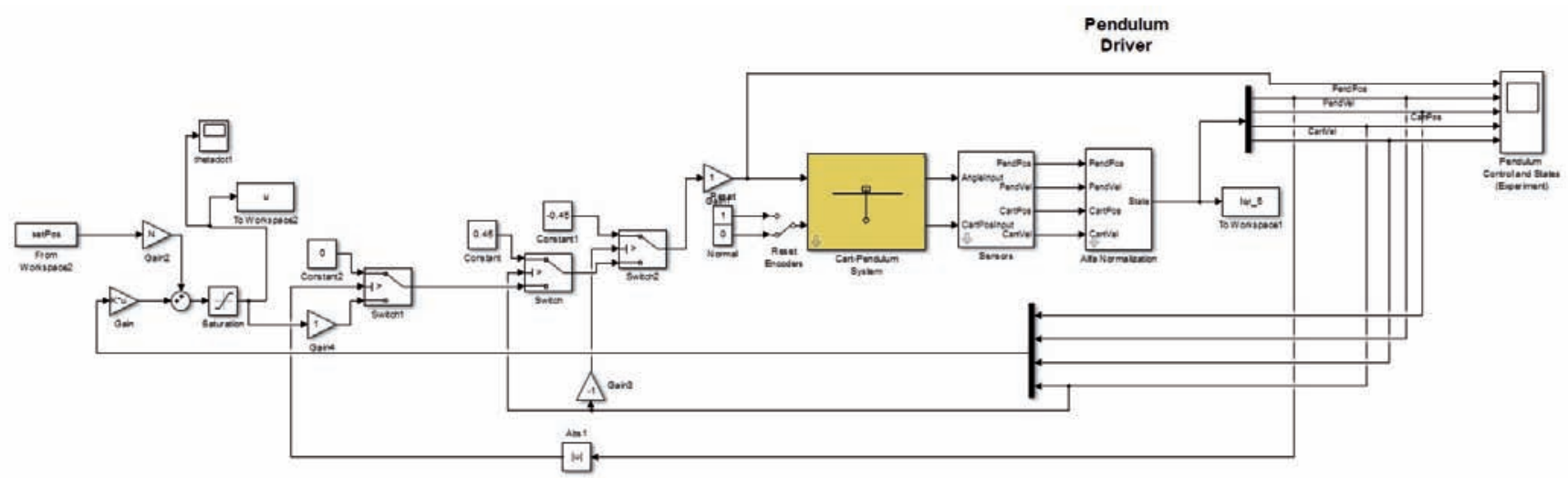

Fig. 9. Implementation of the LQR controller for the inverted pendulum in Simulink

Rys. 9. Implementacja regulatora LQR dla wahadła odwróconego w Simulinku 


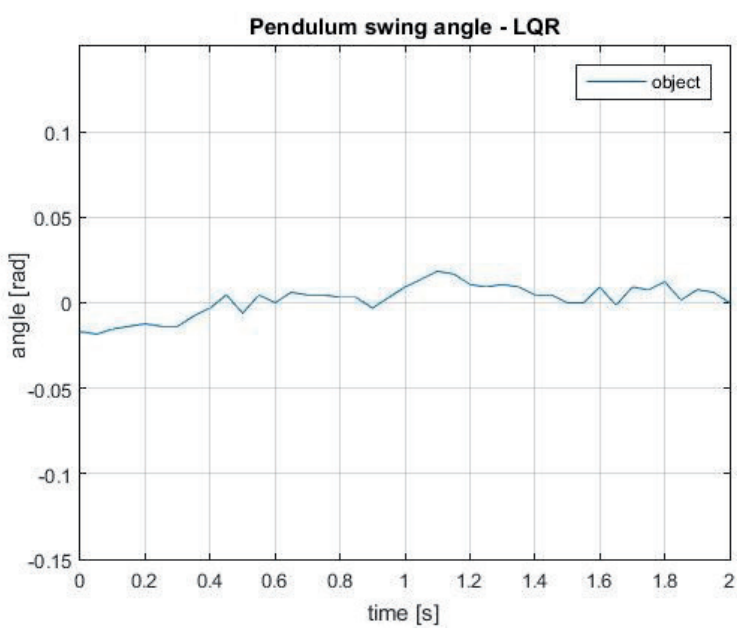

Fig. 10. Pendulum angle (LQR) during the first experiment Rys. 10. Kąt wychylenia wahadła (LQR) - pierwszy eksperyment

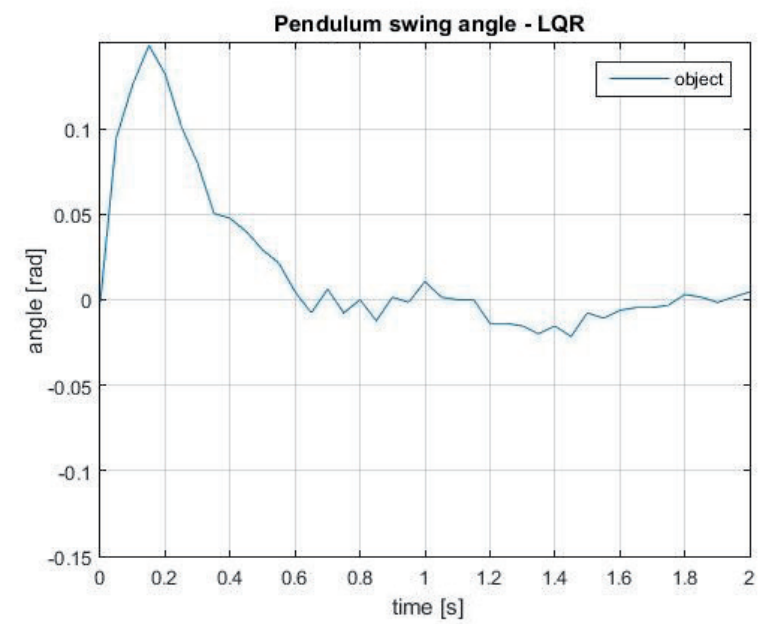

Fig. 11. Pendulum angle (LQR) during the second experiment Rys. 11. Kąt wychylenia wahadła (LQR) - drugi eksperyment

In the second case, the adaptive controller with an additional LQR module was used. The implementation of this controller is shown in figure 12. The adaptive controller is located in the top left corner of the diagram with the LQR part in the bottom left corner (in the same place as in fig. 9). The adaptive controller is in the block called adaptacja. Only two states of the system are brought to it: the position of the pendulum and the speed of the

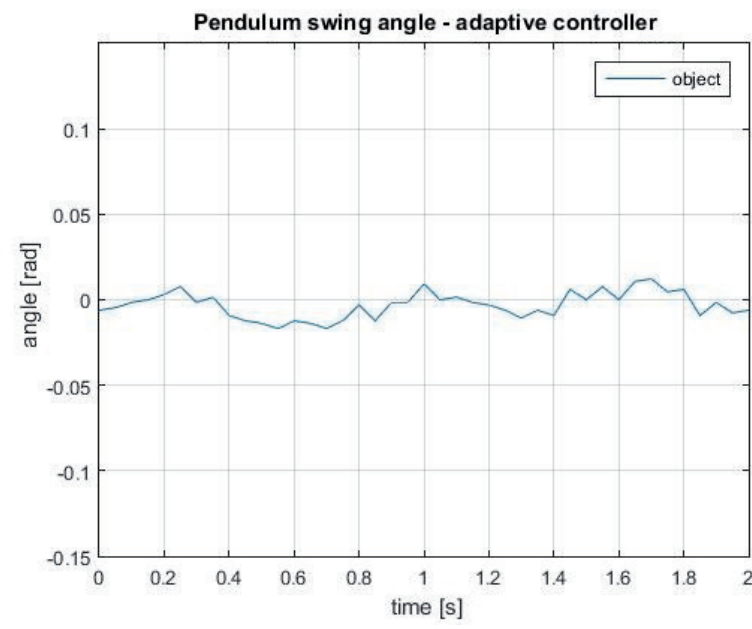

Fig. 13. Pendulum angle (adaptive) during the first experiment Rys. 13. Kąt wychylenia wahadła (regulator adaptacyjny) - pierwszy eksperyment

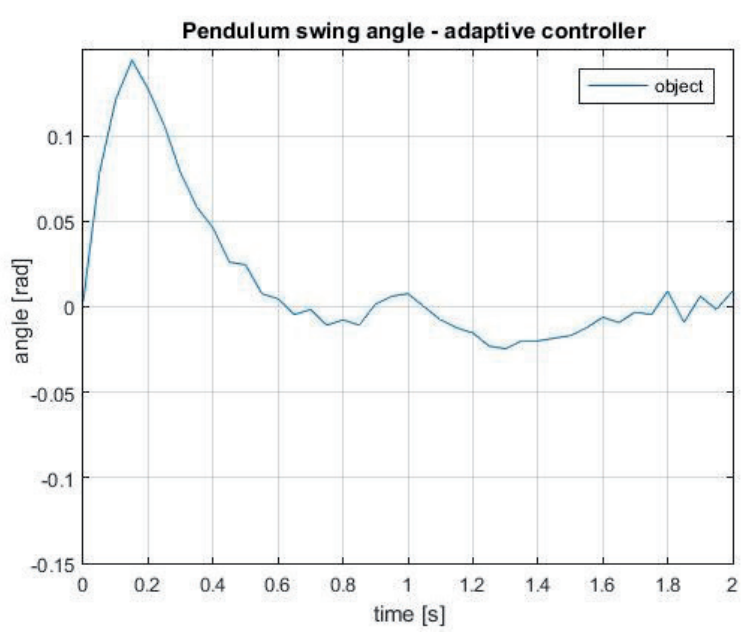

Fig. 14. Pendulum angle (adaptive) during the second experiment Rys. 14. Kąt wychylenia wahadła (regulator adaptacyjny) - drugi eksperyment

pendulum. The calculated control is combined with the calculations from the LQR controller and then fed to the block with saturation. The saturation block is designed to prevent engine damage. In addition, virtual limit sensors have been introduced to prevent the cart from colliding with the rail edges. The experiment was also performed on the PLC controller. The algorithm operated in the $10 \mathrm{~ms}$ interval with the priority set to 0 .

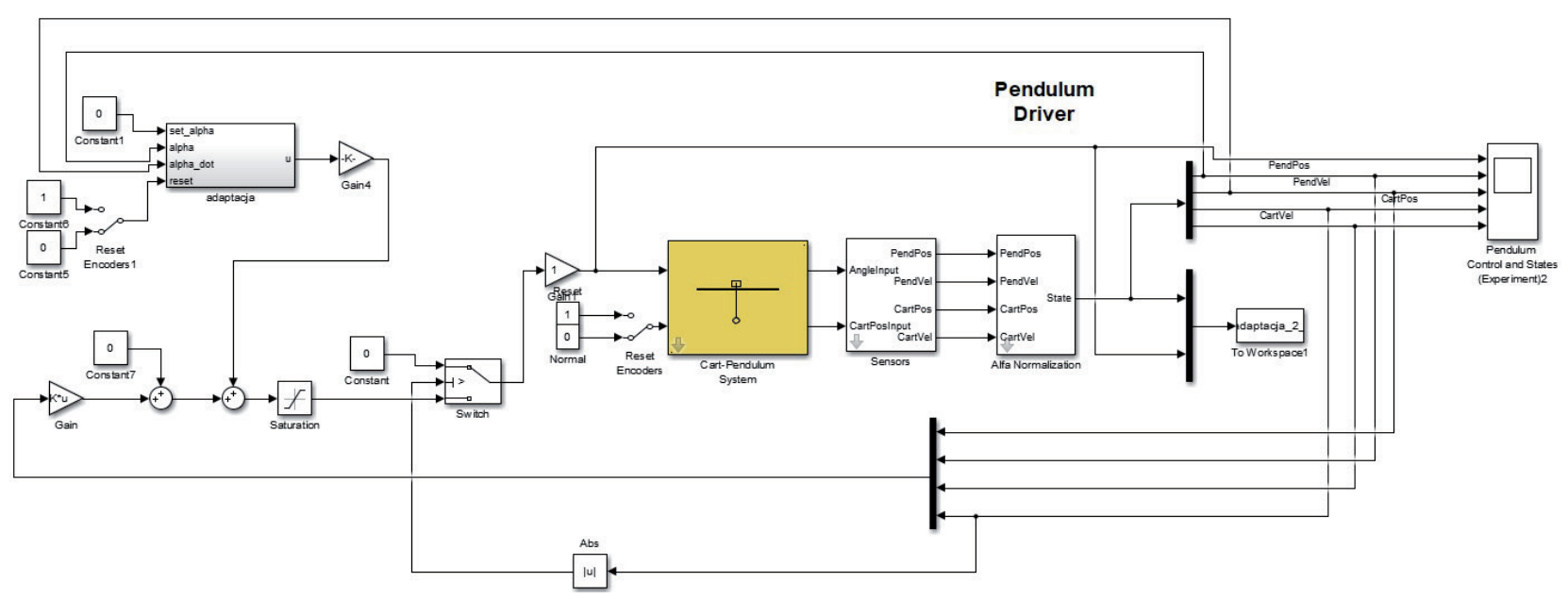

Fig. 12. Implementation of the adaptive controller with additional LQR module for the inverted pendulum in Simulink

Rys. 12. Implementacja regulatora adaptacyjnego z dodatkowym modułem LQR dla wahadła odwróconego w Simulinku 
The results of the first experiment are shown in figure 13 . The pendulum was initially at the upper balance point and it does not fall down and maintains its vertical upright position.

In the second experiment, external disturbances were introduced - gentle prodding of the pendulum with a hand. The results are shown in figure 14. It can be seen on the chart that the pendulum is initially in the set position. However, a disturbance has been introduced. The system returns to the set state very quickly and more smoothly than in the system with the independent LQR regulator. The results of the Integral Square Error cost function for both controllers (40) are shown in tables 3 and 4 .

Tab. 3. Integral indexes - steady states

Tab. 3. Wskaźniki całkowe - stany ustalone

\begin{tabular}{|c|c|}
\hline & Integral indexes \\
\hline LQR & 0.0001662 \\
\hline Adaptive with LQR & 0.0001214 \\
\hline
\end{tabular}

Tab. 4. Integral indexes - external disturbances

Tab. 4. Wskaźniki całkowe - zewnętrzne zakłócenia

\begin{tabular}{|c|c|}
\hline & Integral indexes \\
\hline LQR & 0.00443 \\
\hline Adaptive with LQR & 0.004195 \\
\hline
\end{tabular}

\section{Conclusion}

The adaptive controller was implemented for the purpose of this article. It is one of the advanced algorithms. It takes the position of the pendulum at the entrance. This means that the second one was needed to control the cart. It was decided that the LQR controller must be used for this purpose. The adaptive version only required knowledge of the pendulum's position. The independent LQR controller was used as a reference point for comparison. That particular controller version is characterized by the presence of only one control block, but the position of both the cart and the pendulum must be identified. The knowledge of the speed of the pendulum and the cart is also necessary. Therefore it was necessary to recreate the unknown variables.

After completing the experiments, the Integral Square Error cost function was used to compare the performance of the controllers. It turned out that the adaptive version works a little bit better than the independent LQR. In connection with the results, it can be concluded that it is better to use an adaptive controller. However, it should be remembered that its computational complexity is higher. Therefore, one should consider what is more important - the simplicity of the algorithm or the better quality of the controller.

\section{Bibliography}

1. Aguilar Ibánez C., Gutiérrez Frias O., Suárez Castanón M., Lyapunov-Based Controller for the Inverted Pendulum Cart System, "Nonlinear Dynamics", Vol. 40, No. 4, 2005, 367374, DOI: 10.1007/s11071-005-7290-y.

2. Aguilar- Ibánez C., Suárez-Castanón M., Stabilization of the Inverted Pendulum via a Constructive Lyapunov Function, "Acta Applicandae Mathematicae", Vol. 111, No. 1, 2010, 15-26, DOI: $10.1007 /$ s10440-009-9527-0.
3. Benaskeur A., Desbiens A., Application of adaptive backstepping to the stabilization of the inverted pendulum, Conference Proceedings of IEEE Canadian Conference on Electrical and Computer Engineering, 1998,

DOI: 10.1109/CCECE.1998.682564.

4. Bertrand D.J.S.R., Collins D.J., Neural network controllers for the X29 aircraft, Proceedings of IJCNN International Joint Conference on Neural Networks, Baltimore, MD, USA, 1992, DOI: 10.1109/IJCNN.1992.287191.

5. Charney D.M., Josin G.M., Neural network servo control of a robot manipulator joint in real-time, Proceedings of IEEE International Joint Conference on Neural Networks, Singapore, 1991, DOI: 10.1109/IJCNN.1991.170673.

6. Elsayed B.A., Hassan M.A., Mekhilef S., Fuzzy swinging-up with sliding mode control for third order cart-inverted pendulum system, "International Journal of Control, Automation and Systems", Vol. 13, No. 1, 2015, 238-248, DOI: $10.1007 / \mathrm{s} 12555-014-0033-4$.

7. Gupta H.O., Prasad L.B., Tyagi B., Optimal Control of Nonlinear Inverted Pendulum System Using PID Controller and LQR: Performance Analysis Without and With Disturbance input, "International Journal of Automation and Computing", Vol. 11, Issue 6, 2014, 661-670,

DOI: $10.1007 / \mathrm{s} 11633-014-0818-1$.

8. Hassan H.A., El-Metwally M., Bendary A.F., Dead-zone robust adaptive controller for FACTS using Quadratic and Non-Quadratic Lyapunov Functions, International Conference on Power Electronics and Drive Systems (PEDS), Taipei, 2009, DOI: 10.1109/PEDS.2009.5385747.

9. Inline measurement terminal for position encoder - IB IL INC-IN-PAC - 2861755, https://www.phoenixcontact.com/ online/portal/us?uri=pxc-oc-itemdetail:pid $=2861755 \&$ libra$\mathrm{ry}=\mathrm{usen} \& \mathrm{tab}=1$

10. Inline, function terminal for pulse width modulation and frequency modulation - IB IL PWM/2-PAC - 2861632, https://www.phoenixcontact.com/online/portal/pl?uri=pxc-oc-itemdetail:pid $=2861632 \backslash \&$ library $=$ plpl $\backslash \&$ tab $=1$

11. Jia-Jun W., Position and speed tracking control of inverted pendulum based on double PID controllers, 34th Chinese Control Conference (CCC), Hangzhou, 2015,

DOI: 10.1109/ChiCC.2015.7260286.

12. Jia-Jun W., Stabilization and tracking control of $X-Z$ inverted pendulum based on PID controllers, 34th Chinese Control Conference (CCC), Hangzhou, 2015, DOI: 10.1109/ChiCC.2015.7260287.

13. Lal Bahadur P., Barjeev T., Hari Om G., Optimal Control of Nonlinear Inverted Pendulum System Using PID Controller and LQR: Performance Analysis Without and With Disturbance Input, "International Journal of Automation and Computing", Vol. 11, No. 6, 2014, 661-670, DOI: $10.1007 / \mathrm{s} 11633-014-0818-1$.

14. Luhao W., Zhanshi S., LQR-Fuzzy Control for Double Inverted Pendulum, International Conference on Digital Manufacturing \& Automation, Changsha, 2010, DOI: 10.1109/ICDMA.2010.170.

15. Maruki Y., Kawano K., Suemitsu H., Matsuo T., Adaptive backstepping control of wheeled inverted pendulum with velocity estimator, "International Journal of Control, Automation and Systems", Vol. 12, No. 5, 2014, 1040-1048, DOI: 10.1007/s12555-013-0402-4.

16. Moysis L., Balancing a double inverted pendulum using optimal control an Laguerre functions, Technical Reviews, 2016, http://ikee.lib.auth.gr/record/282764.

17. Paliwal S., Pathak V.K., Analysis 83 Control of Inverted Pendulum System Using PID Controller, "Journal of Engineering Research and Application", Vol. 7, No. 5, DOI: DOI: $10.9790 / 9622-0705040104$. 
18. PLC controller - ILC $350 P N-2876928$, https://www. phoenixcontact.com/online/portal/pl?uri=pxc-oc-itemdetail:pid $=2876928 \backslash \&$ library $=$ plpl $\backslash \&$ tab $=1$

19. Rusu C., Birou I., Szoke E., Model based design controller for the stepper motor, IEEE International Conference on Automation, Quality and Testing, Robotics, Cluj-Napoca, 2008, DOI: 10.1109/AQTR.2008.4588816.

20. Safaei A., Mahyuddin M.N., Lyapunov-based nonlinear controller for quadrotor position and attitude tracking with $G A$ optimization, IEEE Industrial Electronics and Applications Conference (IEACon), Kota Kinabalu, 2016, DOI: 10.1109/IEACON.2016.8067402.

21. User manual - UM EN ILC 330/350 - 2699370, https:// www.phoenixcontact.com/online/portal/us?uri=pxc-oc-itemdetail:pid $=2699370 \&$ library $=$ usen\&tab $=1$.

22. Using the Lagrangian to obtain Equations of Motion, http:// et.engr.iupui.edu// skoskie/ECE680/ECE680_13notes.pdf.
23. Wang H., Dong H., He L., Shi Y., Zhang Y., Design and Simulation of LQR Controller with the Linear Inverted Pendulum, International Conference on Electrical and Control Engineering, Wuhan, 2010,

DOI: 10.1109/iCECE.2010.178.

24. Wu J., Wang Z., Research on Fuzzy Control of Inverted Pendulum, First International Conference on Instrumentation, Measurement, Computer, Communication and Control, Beijing, 2011, DOI: 10.1109/IMCCC.2011.219.

25. Yu L. H., Jian F., An Inverted Pendulum Fuzzy Controller Design and Simulation, International Symposium on Computer, Consumer and Control, Taichung, 2014, DOI: 10.1109/IS3C.2014.151.

26. Yu-Sheng L., Hua-Hsu C., Shu-Fen L., An improved backstepping design for the control of an underactuated inverted pendulum, "Journal of Mechanical Science and Technology", Vol. 27, No. 3, 2013, 865-873, DOI: $10.1007 / \mathrm{s} 12206-013-0203-y$. LQR dla wahadła odwróconego

\author{
Streszczenie: Odwrócone wahadło jest niestabilnym systemem o nieliniowej dynamice. Zadanie \\ sterowania wahadłem odwróconym jest trudne, dlatego też układ ten przez lata stał się jednym \\ z najważniejszych systemów, na których testowane są wszelkiego rodzaju regulatory. Celem \\ sterowania systemem jest ustabilizowanie wahadła odwróconego w pozycji pionowo skierowanej \\ ku górze. W artykule zaproponowano nowy algorytm adaptacyjny dla wahadła, będący kombinacją \\ regulatora LQR oraz regulatora nieliniowego bazującego na twierdzeniu Lapunova. Oba moduły są \\ połączone za pomocą dwupętlowej konstrukcji równoległej. Nowo zaprojektowany regulator został \\ przetestowany eksperymentalnie i porównany z niezależnym modułem LQR.
}

Słowa kluczowe: wahadło odwrócone, regulator adaptacyjny, LQR

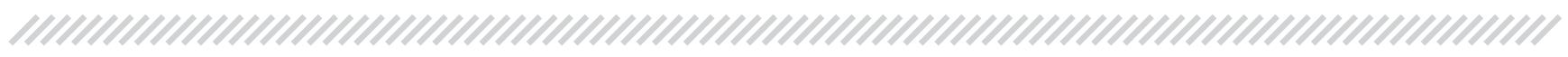

\title{
mgr inż. Jakub Żegleń \\ zeglenjakub@gmail.com \\ ORCID: 0000-0003-1857-1461
}

lakub Żegleń was born in Rabka-Zdrój in 1994. A PhD student at the Faculty of Electrical Engineering, Automatics, Computer Science and Biomedical Engineering of AGH University of Science and Technology in Krakow. A graduate of the ACH University of Science and Technology in the field of automation and robotics from the same faculty. He also graduated from computer science at the Faculty of Mathematics and Computer Science at the Jagiellonian University. In the years 2014-2016 a member of the Integra research club operating at AGH. Since 2016, he has gained professional experience in many reputable companies. His current research interests include PLCs and adaptive controllers.

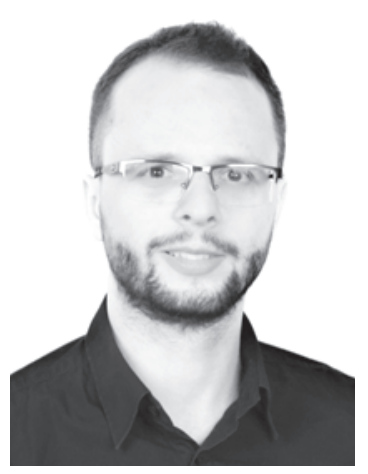

